\title{
Drought and frost resistance vary between evergreen and deciduous Atlantic Forest canopy trees
}

\author{
Débora di Francescantonio (D) A,B,E, Mariana Villagra (D) A,B, Guillermo Goldstein ${ }^{\mathrm{C}}$ \\ and Paula I. Campanello ${ }^{\mathrm{A}, \mathrm{D}}$ \\ ALaboratorio de Ecología Forestal y Ecofisiología, Instituto de Biología Subtropical, Universidad Nacional de \\ Misiones (UNaM)-Consejo Nacional de Investigaciones Científicas y Técnicas (CONICET). Bertoni 85, \\ Puerto Iguazú (N3370BFA), Misiones, Argentina. \\ ${ }^{B}$ Asociación Civil Centro de Investigaciones del Bosque Atlántico (CelBA). Bertoni 85, Puerto Iguazú (N3370BFA), \\ Misiones, Argentina. \\ CLaboratorio de Ecología Funcional, Instituto de Ecología, Genética y Evolución, Instituto IEGEBA (CONICET- \\ UBA), Facultad de Ciencias Exactas y Naturales, Universidad de Buenos Aires, CABA, C1428EGA, Argentina. \\ ${ }^{D}$ Centro de Estudios Ambientales Integrados, Facultad de Ingeniería, Universidad Nacional de la Patagonia \\ San Juan Bosco, CONICET, RN № 259 - Km 16.4, Esquel (9200), Chubut, Argentina. \\ ${ }^{E}$ Corresponding author. Email: debodifra@gmail.com
}

\begin{abstract}
Frost and drought are key stress factors limiting the growth and distribution of tree species. Resistance to stress involves energy costs that may result in trade-offs between different functional traits. Structures or mechanisms that can help to withstand stress imply differences in the carbon economy of the species. Although adaptive responses to frost and drought resistance are usually of a similar nature, they are rarely assessed simultaneously. We investigated these resistance mechanisms in 10 canopy tree species coexisting in the semi-deciduous subtropical forests of northern Argentina. We measured leaf lifespan, anatomical, photosynthetic and water relations traits and performed a thermal analysis in leaves to determined ice nucleation and tissue damage temperatures. Our results showed that evergreen and deciduous species have different adaptive responses to cope with freezing temperatures and water deficits. Evergreen species exhibited cold tolerance, while deciduous species were more resistant to hydraulic dysfunction and showed greater water transport efficiency. Further research is needed to elucidate resistance strategies to stress factors at the whole tree- and stand level, and possible links with hydraulic safety and efficiency among different phenological groups. This will allow us to predict the responses of subtropical forest species to changes in environmental conditions under climate change scenarios.
\end{abstract}

Additional keywords: electron transport rate, frost resistance, hydraulic traits, leaf economics spectrum, leaf habit, trade-off, turgor loss point, water availability.

Received 5 October 2019, accepted 27 March 2020, published online 9 June 2020

\section{Introduction}

Resistance of species to stress events is determined by the interaction of multiple functional traits (Bartlett et al. 2016). The interspecific variation of these traits can increase species richness (Ben-Hur et al. 2012) and promote their coexistence (Clark et al. 2010; Uriarte et al. 2010; Anderegg and Hillerislambers 2016). Low temperatures and water availability are two of the main stressors limiting the growth and geographical distribution of tree species growing beyond the tropical regions. Both stress factors affect important plant physiological processes such as photosynthesis, photoinhibition, and transpiration (Sakai and Larcher 1987; Stuart et al. 2007; Charra-Vaskou et al. 2012).
The exchange of gases through stomata, and the fixation of carbon in photosynthetic tissues are two important physiological processes in leaves (Poorter et al. 2008; Martínez-Vilalta et al. 2010; Wright et al. 2010; Iida et al. 2016). To operate optimally, these processes require a wellbalanced hydration status of the leaf. This water status is associated with stomatal regulation as well as water transport in leaves through inside and outside the xylem pathway (Prado and Maurel 2013; Buckley et al. 2015; Scoffoni et al. 2017). Small variations in the water flow through leaves have important implications on the water transport at plant level (Holbrook and Zwieniecki 2005), and could strongly limit productivity, competitive 
success, and ultimately species distribution (Sack and Holbrook 2006).

Evergreen and deciduous species represent the opposite extremes in the leaf economics spectrum from conservative and slow-growing to acquisitive and fast-growing, respectively, as suggested by correlations among photosynthetic rate, leaf lifespan (LL), and specific leaf area (SLA) (Wright et al. 2004; Bai et al. 2015). Further, the leaf economics framework was extended to a more general plant economic spectrum incorporating wood and hydraulic traits (Reich 2014; Xu et al. 2017). Wood density (WD) is functionally related to carbon gain, and regulation of leaf water status (Santiago et al. 2004; Jacobsen et al. 2007; Chave et al. 2009; Oliva Carrasco et al. 2015).

Adaptations to freezing and drought often share similar physiological mechanisms (Atkin et al. 2005; Beck et al. 2007; Costa e Silva et al. 2009). Tree species exhibit three strategies to resist these stress factors: escape, avoidance, and tolerance (Levitt 1980; Hódar et al. 2004; Körner 2012). Deciduous trees usually escape the effect of freezing or drought by adjusting leaf phenology to seasonal changes (Cavender-Bares et al. 2005; Pennington et al. 2009; Hasselquist et al. 2010; Wolfe and Kursar 2015). Avoidance can be regarded as the minimisation or the exclusion of the stress effect on a given tissue (Vitasse et al. 2014). Examples of this include supercooling (Goldstein et al. 1985; Wisniewski et al. 2015), rolling of leaves (Schwabe and Lionakis 1996) and strongly lignified tissues (Richardson and Berlyn 2002). Tolerance is achieved via morphological, anatomical, and biochemical changes to allow osmotic and elastic adjustment of tissues (Preston and Sandve 2013). Both drought- and freezing-tolerant species resist cell dehydration (Charra-Vaskou et al. 2012). Although frost and drought resistances in leaves may be correlated (Medeiros and Pockman 2011), simultaneous measurements and analysis on these adaptive responses for a large number of species are lacking.

The Atlantic Forest biome is located in South America, covering a great extension of the Brazilian coast and extending from up to $700 \mathrm{~km}$ to the continent to Argentina and Paraguay. In its subtropical part, deciduous trees comprise a substantial percentage $(25-50 \%)$ of the species (Leite and Klein 1990; Rezende et al. 2016). Despite the mild seasonality in temperatures and rainfall, there is little research examining plant strategies in subtropical forests and, particularly, in the semi-deciduous Atlantic Forest. The aim of the present study was to evaluate the resistance mechanisms to drought and low temperatures in relation to leaf habit, wood density, and leaf anatomical, hydraulic, and photosynthetic traits in 10 canopy tree species coexisting in the semi-deciduous Atlantic Forest in NE Argentina. Mechanisms of stress resistance imply tradeoffs among different functional traits with high energy costs (Xu et al. 2009; Onoda et al. 2011). According to the leaf economic spectrum framework we expected that species with long leaf lifespan have traits that allow them to avoid or tolerate frost and drought stress. Species with short leaf lifespan, which escape subzero temperatures, have leaf traits associated with maximising carbon assimilation and water transport efficiency during the growing season at the expense of drought resistance.

\section{Materials and methods}

Study site

The present study was conducted in the semi-deciduous Atlantic Forest at Iguazú National Park, Misiones province, Argentina $\left(25^{\circ} 41^{\prime}-25^{\circ} 42^{\prime} \mathrm{S}, 54^{\circ} 28^{\prime}-54^{\circ} 29^{\prime} \mathrm{W}\right)$. This forest has mature canopy trees ranging from 20 to $45 \mathrm{~m}$ in height, with abundant lianas and epiphytic species (Srur et al. 2007). This subtropical forest contains more than 70 tree species (GalindoLeal and Gusmão Câmara 2003) including evergreen, and winter deciduous and brevideciduous species (Pennington et al. 2009). The mean annual rainfall is $2000 \mathrm{~mm}$, evenly distributed throughout the year. Exceptionally intense and short-lived droughts may occur during the year, where soil water potentials can attain values as low as $-2 \mathrm{MPa}$ (Campanello et al. 2009). The annual mean air temperature is $21^{\circ} \mathrm{C}$. Additionally, freezing temperatures (frosts) of 2-9 days per year occur during autumn-winter (Srur et al. 2007; Gatti et al. 2008).

In order to evaluate the traits associated with resistance to low temperatures and water deficits, thermal analyses and measurements of hydraulic, anatomical, and photosynthetic leaf traits were carried out in 10 tree canopy species of the semi-deciduous Atlantic Forest: Ceiba speciosa (A.St.-Hil., A. Juss. \& Cambess.) Ravenna, Cedrela fissilis Vell., Cordia trichotoma (Vell.) Arráb. Ex Steud., Cabralea canjerana (Vell.) Mart., Ocotea diospyrifolia (Meisn.) Mez., Chrysophyllum gonocarpum (Mart. \& Eichler) Engl, Balfourodendron riedelianum (Engl.) Engl., Lonchocarpus muehlbergianus Hassl, Parapiptadenia rigida (Benth.) Brenan, and Holocalyx balansae Micheli. Values of WD employed in this study were obtained according to Oliva Carrasco et al. (2015). Species selection was based according to their relatively high abundance, which additionally covered a wide range of WD values, and represented different leaf habits characteristic of the semideciduous Atlantic Forest (Zuloaga et al. 2008; Jardim Botânico do Rio de Janeiro 2018; see di Francescantonio et al. 2018 for details).

Monthly precipitation and temperature data for the study period (see Fig. S1, available as Supplementary Material to this paper) were obtained from the nearest $(8 \mathrm{~km})$ meteorological station (Puerto Iguazú-Aero, Servicio Meteorológico Nacional, Argentina, $25^{\circ} 43^{\prime} 48^{\prime \prime} \mathrm{S}-$ $\left.54^{\circ} 28^{\prime} 12^{\prime \prime} \mathrm{W}\right)$.

\section{Leaf lifespan}

In 2012, two trees per species were selected to measure LL. Depending on the species, two to three branches between 13 and $18 \mathrm{~m}$ high were selected, where a minimum of 20 recently expanded leaves with unique identifiers was marked. The presence of tagged leaves was monthly recorded. Survival time and LL for each species at the time from full leaf expansion to abscission were estimated with the Kaplan-Meier method (Kitajima et al. 2013; Russo and Kitajima 2016), which accounts for censored leaves (leaves 
removed from the study before their death or alive at the last survival census).

\section{Anatomical and photosynthetic leaf traits}

The methodologies described in Pérez-Harguindeguy et al. (2013) were used for determining specific leaf area (SLA) and venation traits in 10 and three leaves per species, respectively. The leaves were cleared to quantify venations traits. For this purpose, leaves were boiled in $96 \%$ alcohol, and then in a solution of $5 \% \mathrm{NaOH}$ and $96 \%$ ethanol, $1: 1(\mathrm{v} / \mathrm{v})$. The time of boiling varied according to the hardness of leaves tissue. Then, leaves were washed in distilled water and transferred into a sodium hypochlorite solution, until they were transparent. Finally, the tissues rich in lignin were stained with a solution of $2 \%$ safranin in ethanol, and scanned at $600 \mathrm{dpi}$. Whole cleared leaf images were measured to estimate leaf area, and density of 1 st and 2nd veins. Vein density (VD) was measured as the total length of the 1 st and the 2 nd order leaf venations per leaf area using ImageJ (NIH Image) by manually drawing and counting all veins in the leaf area. The leaves used to study venation were also used to determine the stomatal density (SD). Clear nail polish was applied onto the middle of the abaxial and adaxial leaf surface (avoiding the major vein). After they were dried, they were peeled off and mounted onto a glass slide to obtain images that were captured using a light microscope with $40 \times$ magnifications (Leica Lietz DMRB; Leica Microsystems, with Nikon Coolpix 4500 digital) (Russo et al. 2010).

To estimate leaf photosynthetic capacity a chlorophyll fluorescence analyser with a pulse-amplitude modulated yield (Mini-PAM Walz) was used. Three to four individuals per species were selected during spring. Leaves used had similar size and sun exposure. Electron transport rate (ETR) was calculated based on chlorophyll fluorescence data using the following equation:

$$
\mathrm{ETR}=\Phi \text { PSII } \times \text { PFD } \times 0.5 \times \alpha,
$$

where ETR is electron transport rate, PSII is the effective quantum yield of $\Phi$ PSII measured during a 0.8-s saturating flash (2000-3000 $\mu \mathrm{mol} \mathrm{m} \mathrm{m}^{-2} \mathrm{~s}^{-1}$ ), and the coefficient of 0.5 factor assumes an even distribution of absorbed quanta between PSII and PSI so that two photons are required for each electron passed through (Maxwell and Johnson 2000). The $\alpha$ parameter was assumed to be 0.84 as a mean value for a wide variety of leaves (Björkman and Demmig 1987; Stemke and Santiago 2011). Photosynthetic capacity, expressed as the maximum electron

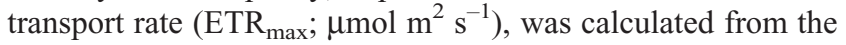
light curves as described by Rascher et al. (2000):

$$
y=\left(\operatorname{ETR}_{\max }\right)\left(1-\mathrm{e}^{-\mathrm{bx}}\right),
$$

where $y$ is photosynthetic rate, $x$ is irradiance, and $b$ is the instantaneous fractional growth rate of the exponential function.

\section{Thermal analysis and tissue damage \\ Ice nucleation temperatures of leaves}

Thermal analyses of mature leaves were conducted to determine the ice nucleation temperature (INT). During the months of April and May 2016, sun-exposed branches from three individuals of each species were collected early in the morning and immediately covered by black plastic bags and transported to the laboratory. Leaves were placed in a temperature controlled freezer in contact with copperconstantan thermocouples in order to determine tissue temperature. One thermocouple was attached with surgical tape (Transpore, 3M) against the underside of each leaf and was positioned in a tube within the freezer. The thermocouples were connected to an automatic data acquisition system (CR10X, Campbell Scientific), and temperatures were recorded at 4-s intervals. Freezer temperature was lowered at a rate of $5^{\circ} \mathrm{C} \mathrm{h}^{-1}$ from ambient $\left(20^{\circ} \mathrm{C}\right)$ to $-10^{\circ} \mathrm{C}$. This rate was similar to those used in other studies (e.g. Lipp et al. 1994; Arias et al. 2015). Foliar INT was obtained from the tissue temperature kinetics. A rapid increase in temperature indicated heat release from water during extracellular ice nucleation.

\section{Leaf tissue damage}

The electrolyte leakage method was used to assess the impact of low temperatures on leaf tissue damage (Wilner 1960; Lipp et al. 1994). Leaves samples from the same branches used in thermal analysis were placed into sealed tubes (16 leaf discs per tube, 11 tubes per individual, three individuals per species) and incubated in a freezer. The freezer was then cooled down at a rate of $5^{\circ} \mathrm{C} \mathrm{h}^{-1}$ to reach different target temperatures $(20$, $10,7,5,2,0,-2,-4,-6,-8$ and $\left.-10^{\circ} \mathrm{C}\right)$. After maintaining the samples at the target temperature for 15 min (Lipp et al. 1994), 3 tubes per species (one of each individual) were removed from the freezer and thawed at ambient-temperature $\left(20^{\circ} \mathrm{C}\right)$ for $2 \mathrm{~h}$, and then $20 \mathrm{~mL}$ of deionised water was added to each tube. The tubes were held at $20^{\circ} \mathrm{C}$ for $24 \mathrm{~h}$ with occasional mixing and shaking, and then the electrical conductivity (EC) of the solution was measured with an electrical conductance/ resistance meter (Lutron WA-2015). The samples were frozen at $-20^{\circ} \mathrm{C}$ for $24 \mathrm{~h}$ to achieve a complete electrolyte leakage, and then the EC of the solution was measured once again. The relative EC was calculated as a percentage:

relative $\mathrm{EC}=(\mathrm{EC}$ after the temperature treatment $/ \mathrm{EC}$

$$
\text { at } \left.-20^{\circ} \mathrm{C}\right) \times 100 \text {. }
$$

The \% EC was plotted as a function of the incubation temperature. The temperature at $50 \%$ relative EC was defined as the leaf lethal temperature of the species $\left(\mathrm{LT}_{50}\right)$ which could be associated with membrane structural transitions (Rajashekar et al. 1979).

The thermal safety margin (TSM) was defined for each species as:

$$
\mathrm{TSM}=\mathrm{INT}-\mathrm{LT}_{50} .
$$

Species that exhibited $\mathrm{LT}_{50}$ within the range of INT $(\mathrm{TSM}=0)$ were categorised as freezing-avoidant species (FAS), in cases where $\mathrm{LT}_{50}$ was greater than INT $(\mathrm{TSM}<0)$ the species were considered sensitive to extracellular ice formation (freezing sensitive species, FSS), whereas species with $\mathrm{LT}_{50}$ being sustainably lower than INT (TSM $>0$ ) were categorised as freezing-tolerant species (FTS) (Squeo et al. 1991; Zhang et al. 2016). 


\section{Leaf water relations}

Leaf water potentials at predawn $\left(\Psi_{\mathrm{pd}}\right)$ and midday $\left(\Psi_{\mathrm{md}}\right)$ were measured in 4-5 leaves in three individuals per species with a pressure chamber (PMS1000) during a 30-day dry spell on January 2012. The $\Psi_{\text {md }}$ values obtained in these conditions reflect the minimum leaf water potential for these species under natural conditions (Bhaskar and Ackerly 2006). The $\Psi_{\mathrm{pd}}$ and $\Psi_{\mathrm{md}}$ were determined at 05:30-07:00 hours and 12:30-14:00 hours respectively.

Pressure-volume analyses were obtained using the dehydration technique (Tyree and Hammel 1972; Koide et al. 1989). Branches of three individuals per species were collected at predawn and transferred immediately to the laboratory in sealed plastic bags. Volumetric bulk modulus of elasticity $(\varepsilon)$ was calculated over the full range of positive turgor as described by (Evans et al. 1990):

$$
\varepsilon=(\Delta \Phi \mathrm{P} / \Delta \mathrm{RWC}),
$$

where $\triangle \Psi P$ is the change in turgor pressure and $\triangle \mathrm{RWC}$ is the change in relative water content and FS is the symplastic water fraction.

Leaf hydraulic conductance $\left(K_{\text {leaf }} ; \mathrm{mmol} \mathrm{m}^{-2} \mathrm{~s}^{-1} \mathrm{MPa}^{-1}\right)$ was determined according to the partial rehydration method (Brodribb and Holbrook 2003). The $K_{\text {leaf }}$ was calculated as:

$$
K_{\text {leaf }}=C \ln \left(\Psi_{\mathrm{i}} \Psi_{\mathrm{f}}\right) / t
$$

where $\mathrm{C}$ is leaf capacitance, $\Psi_{\mathrm{i}}$ is the foliar water potential before rehydration and $\Psi_{\mathrm{f}}$ is the foliar water potential after rehydration for $t$ seconds. Foliar capacitance was determined from the $\mathrm{P}-\mathrm{V}$ relationships. Leaf vulnerability was determined by plotting $K_{\text {leaf }}$ against $\Psi_{\mathrm{i}}$. The water potential at which loss of 50 and $88 \%$ of leaf hydraulic conductance occurs $\left(\mathrm{P}_{50}\right.$ and $\mathrm{P}_{88}$ respectively) and $K_{\text {leaf_max }}$ was estimated from a four-parameter logistic function fitted to the data.

The hydraulic safety margin (HSM), which reflects the preservation of hydraulic integrity, was calculated as follows:

$$
\begin{aligned}
& \operatorname{HSM}_{\mathrm{P} 50}=\Psi_{\mathrm{md}}-\mathrm{P}_{50}, \\
& \mathrm{HSM}_{\mathrm{P} 88}=\Psi_{\mathrm{md}}-\mathrm{P}_{88},
\end{aligned}
$$

where $\Psi_{\text {md }}$ is minimum leaf water potential, $\mathrm{P}_{50}$ and $\mathrm{P}_{88}$ are the leaf water potential inducing a 50 and $88 \%$ loss in the leaf hydraulic conductance respectively.

\section{Statistical analysis}

Sigmoid curves were fitted to the relationship between relative EC and temperature for all the species. Then, $\mathrm{LT}_{50}$ were derived from the regression equations. $\mathrm{P}_{50}, \mathrm{P}_{88}$ and $K_{\text {leaf_max }}$ were estimated from a four-parameter sigmoid function fitted to the data. The relationship between INT, and $\mathrm{LT}_{50}$ with leaf habits (deciduous, brevideciduous and evergreen) were analysed using two independent linear mixed-effects models. Leaf habit was considered as a fixed effect and species a random effect. A model with a normal distribution and an identity link function was fitted to the data using the lme function (package nlme) (Pinheiro et al. 2017) in the $\mathrm{R}$ statistical and programming environment ( $\mathrm{R}$ Development Core Team 2016). The significance of fixed effects was assessed using Fisher's test and post-hoc comparisons were carried out using Tukey's test in the multcomp R package (Hothorn et al. 2016). Finally, to evaluate trait coordination between deciduous-brevideciduous and evergreen species, statistically significant correlations among traits (with $\mathrm{r}>0.6$, and $P<0.05$ ) were graphically represented using trait covariation networks. Traits were represented as nodes and their correlation as the edges linking them. Two indicators of network centrality were calculated for each trait: the degree (D), defined as the number of edges of a node and the weighted degree (Dw), defined as the sum of all significant coefficients of correlation of a node. Pearson correlations and Kaplan-Meier method were performed with InfoStat software (Di Rienzo et al. 2017).

\section{Results}

\section{Leaf lifespan}

Evergreen species, with leaves always present, showed LL from 438 to 479 days; brevideciduous species, with leaves absent for 1 month or less of the year, presented LL of 269-354 days; and deciduous species, with leaves absent for more than 1 month, presented LL of 208 and 329 days (Table 1; Fig. S2).

\section{Anatomical traits and specific leaf area}

No relationship was found between leaf habits and stomatal density $\left(\mathrm{F}_{2,27}=0.63, P=0.54\right)$, or density of major veins $\left(\mathrm{F}_{2,27}=1.58, P=0.22\right)$. There were considerable differences

\begin{tabular}{|c|c|c|c|c|c|c|c|}
\hline Family & Species & Leaf habit & $\mathrm{SD}$ & VD & $\mathrm{LL}_{\max }$ & SLA & WD \\
\hline Meliaceae & Cedrela fissilis & $\mathrm{D}$ & $142.8 \pm 3.0$ & $2.3 \pm 0.4$ & 329 & $97.6 \pm 9.2$ & $0.49 \pm 0.01$ \\
\hline Boraginaceae & Cordia trichotoma & $\mathrm{D}$ & $33.6 \pm 5.2$ & $1.2 \pm 0.02$ & 208 & $66.7 \pm 5.3$ & $0.59 \pm 0.02$ \\
\hline Malvaceae & Ceiba speciosa & $\mathrm{D}$ & $36.2 \pm 1.0$ & $3.2 \pm 0.3$ & 210 & $105.2 \pm 7.4$ & $0.41 \pm 0.02$ \\
\hline Rutaceae & Balfourodendron riedelianum & B & $38.8 \pm 2.0$ & $2.2 \pm 0.1$ & 319 & $115.1 \pm 12.7$ & $0.66 \pm 0.02$ \\
\hline Fabaceae & Parapiptadenia rigida & B & $90.2 \pm 7.5$ & $12.6 \pm 1.3$ & 269 & $114.5 \pm 11.8$ & $0.78 \pm 0.02$ \\
\hline Fabaceae & Lonchocarpus muehlbergianus & B & - & $2.1 \pm 0.1$ & 354 & $143.1 \pm 12.3$ & $0.76 \pm 0.03$ \\
\hline Meliaceae & Cabralea canjerana & $\mathrm{E}$ & $23.0 \pm 3.0$ & $1.6 \pm 0.1$ & 438 & $116.7 \pm 14.0$ & $0.56 \pm 0.02$ \\
\hline Lauraceae & Ocotea diospyrifolia & $\mathrm{E}$ & $39.4 \pm 2.4$ & $1.6 \pm 0.1$ & 442 & $112.7 \pm 2.5$ & $0.56 \pm 0.01$ \\
\hline Fabaceae & Holocalyx balansae & $\mathrm{E}$ & $61.2 \pm 0.5$ & $11.9 \pm 0.1$ & 479 & $113.9 \pm 7.6$ & $0.83 \pm 0.01$ \\
\hline Sapotaceae & Chrysophyllum gonocarpum & $\mathrm{E}$ & $85.9 \pm 7.5$ & $2.4 \pm 0.5$ & 468 & $118.1 \pm 26.4$ & $0.66 \pm 0.02$ \\
\hline
\end{tabular}

Table 1. Family, species, leaf habit, leaf anatomical traits and wood density

Stomatal density ( $\mathrm{SD}$, stomatal $\mathrm{mm}^{-2}$ ), vein density, $\left(\mathrm{VD}, \mathrm{mm} \mathrm{mm}^{-2}\right)$, maximum leaf lifespan $\left(\mathrm{LL}_{\max }\right.$, days), specific leaf area (SLA, $\left.\mathrm{cm}^{2} \mathrm{~g}^{-1}\right)$, wood density (WD, $\mathrm{g} \mathrm{cm}^{-3}$ ). D, deciduous; B, brevideciduous; E, evergreen. Values are means \pm s.e. $\left(n=3\right.$ for SD and VD; $n=20$ for $\mathrm{LL}_{\max } ; n=6-10$ for SLA and WD) 
among species. Stomatal density ranged between $23.0 \pm 3.0$ stomata $\mathrm{mm}^{-2}$ in C. canjerana to $142.8 \pm 3.0$ stomata $\mathrm{mm}^{-2}$ in C. fissilis; whereas major vein density ranged between $1.2 \pm 0.02 \mathrm{~mm} \mathrm{~mm}^{-2}$ in $C$. trichotoma to $12.6 \pm 1.3 \mathrm{~mm}$ $\mathrm{mm}^{-2}$ in $P$. rigida (Table 1). Species with trichomes on the leaf surface ( $C$. fissilis and $C$. trichotoma) showed the lower values in SLA (Table 1).

\section{Thermal analysis and tissue damage}

The relationship between membrane damage (EC), and the leaf tissue temperature was described by a sigmoid function for all species (Fig. S3). INT as well as the temperature at which $50 \%$

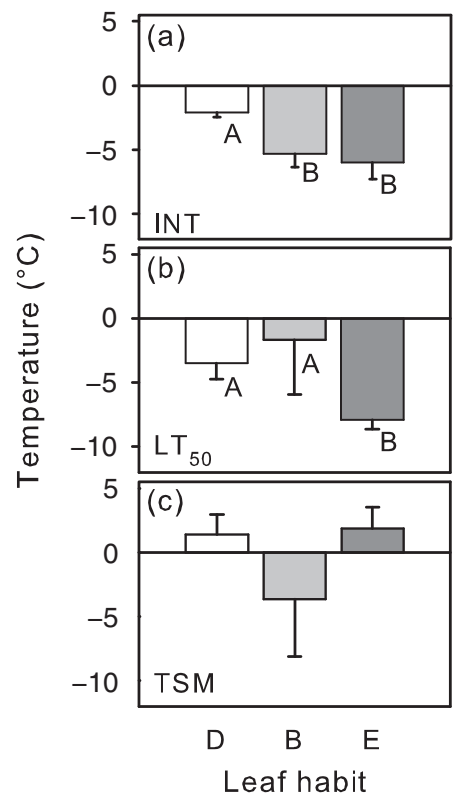

Fig. 1. Ice nucleation temperature $(a)$, leaf lethal temperature $(b)$, and thermal safety margin $(c)$ for leaf habits. $\mathrm{D}$, deciduous species (Cedrela fissilis, Cordia trichotoma, Ceiba speciosa); B, brevideciduous species (Balfourodendron riedelianum, Parapiptadenia rigida, Lonchocarpus muelhlbergianus); E, evergreen species (Cabralea canjerana, Ocotea diospyrifolia, Holocalyx balansae, Chrysophyllum gonocarpum). Different letters indicate significant differences at $P<0.05$. membrane electrolyte leakage occurred (i.e. leaf lethal temperature, $\mathrm{LT}_{50}$ ) varied across species and was different between leaf habits $\left(\mathrm{F}_{2,27}=12.10, P<0.001 ; \mathrm{F}_{2.27}=7.05\right.$, $P<0.01$ respectively; Fig. $1 a, b$; Table 2), whereas TSM did not show significant differences $\left(\mathrm{F}_{2,27}=2.86, P=0.07\right.$; Fig. 1c). Deciduous species had higher nucleation temperatures and $\mathrm{LT}_{50}$ than the evergreen species. FTS was observed in the evergreen species and in one of the brevideciduous species studied, with $\mathrm{LT}_{50}$ substantially lower than the INT values. FAS was observed in the deciduous and in one brevideciduous species. In these cases, $\mathrm{LT}_{50}$ was within the range of the INT (Table 2). Two species (L. muehlbergianus and $H$. balansae) were FSS, their $\mathrm{LT}_{50}$ was greater than INT.

The INT and $\mathrm{LT}_{50}$ were negatively related to $\mathrm{LL}_{\max }(r=-0.51$, $P=0.03$ and $r=-0.77, P<0.001$ respectively). Species with longer $\mathrm{LL}_{\max }$ showed lower values of INT and $\mathrm{LT}_{50}$ (Fig. $2 a, b$; Table 2). WD showed a significant negative relationship with INT $(r=-0.67, P=0.001)$, but there was no relationship between WD and $\operatorname{LT}_{50}(r=-0.27, P=0.17)$ (Fig. $\left.2 c, d\right)$.

\section{Leaf water relations and photosynthetic leaf traits}

The isohydricity (daily $\Delta \Psi$ ) of the 10 species studied showed a continuum of responses, not depending on their leaf habit (Fig. S4; Table 3). The $\mathrm{K}_{\text {leaf }}$ decreased as $\Psi_{\text {leaf }}$ became more negative (Fig. S5). In general, $K_{\text {leaf_max }}$ was higher in deciduous than in evergreens species (Table 3). Also, $K_{\text {leaf_max }}$ varied widely among species, being six times greater in $C$. speciosa than in $C$. gonocarpum (Table 3). $\Psi_{\text {md }}$ did not vary across the different leaf habits $\left(\mathrm{F}_{2,27}=0.59, P=0.56\right.$; Fig. $\left.3 a\right)$, whereas significant differences were found in $\mathrm{P}_{50}$ and $\mathrm{P}_{88}\left(\mathrm{~F}_{2,27}=21.7, P<\right.$ $0.001 ; \mathrm{F}_{2.27}=12.7, P<0.001$, respectively, Fig. $\left.3 b, c\right)$. Deciduous species lost hydraulic conductivity at more negative water potentials than evergreens. The $\mathrm{HSM}_{\mathrm{P} 88}$ also varied with leaf habit $\left(\mathrm{F}_{2,27}=19.55, P<0.001\right)$. These safety margins were positive or near zero in deciduous and brevideciduous species and negative in evergreen species (Fig. 3d).

The $\mathrm{ETR}_{\max }$ was negatively related to LL $(r=-0.6$, $P=0.03)$, while no relationship was found with wood

Table 2. Extracellular ice nucleation temperature (INT, $\left.{ }^{\circ} \mathrm{C}\right)$, leaf lethal temperature $\left(\mathrm{LT}_{50}\right.$; the temperature at which $\mathbf{5 0 \%}$ membrane leakage electrolyte occurred, ${ }^{\circ} \mathrm{C}$ ), thermal safety margin $\left(\mathrm{TSM},{ }^{\circ} \mathrm{C}\right)$ and frost resistance adaptations Abbreviations: FAS, freezing avoidant species; FTS, freezing tolerant species; FSS, freezing sensitive species. Values are means \pm s.e. $(n=3)$. Significant differences are indicated: $*, P<0.05 ; * *, P<0.001$

\begin{tabular}{lcrrc}
\hline Species & INT & LT $_{50}$ & TSM & Frost resistance \\
\hline Cedrela fissilis & $-1.45 \pm 0.13$ & $-5.41 \pm 1.20$ & $3.96 \pm 2.28$ & FAS \\
Cordia trichotoma & $-2.27 \pm 0.38$ & $-3.88 \pm 1.57$ & $1.61 \pm 0.85$ & FAS \\
Ceiba speciosa & $-2.60 \pm 0.62$ & $-1.21 \pm 0.76$ & $-1.39 \pm 1.25$ & FAS \\
Balfourodendron riedelianum & $-3.53 \pm 0.52$ & $-6.24 \pm 0.12$ & $2.71 \pm 0.45$ & FTS* \\
Parapiptadenia rigida & $-7.01 \pm 0.93$ & $-5.62 \pm 0.40$ & $-1.39 \pm 0.79$ & FAS \\
Lonchocarpus muehlbergianus & $-5.50 \pm 0.28$ & $6.79 \pm 1.38$ & $-12.30 \pm 1.10$ & FSS $^{* *}$ \\
Cabralea canjerana & $-3.78 \pm 0.22$ & $-7.29 \pm 1.04$ & $3.51 \pm 0.85$ & FTS* $^{*}$ \\
Ocotea diospyrifolia & $-6.92 \pm 0.12$ & $-9.68 \pm 0.01$ & $2.76 \pm 0.11$ & FTS $^{* *}$ \\
Hlocalyx balansae & $-9.27 \pm 0.68$ & $-6.14 \pm 0.12$ & $-3.13 \pm 0.59$ & FSS* $^{*}$ \\
Chrysophyllum gonocarpum & $-4.12 \pm 0.38$ & $-8.42 \pm 0.69$ & $4.30 \pm 0.71$ & FTS* \\
\hline
\end{tabular}




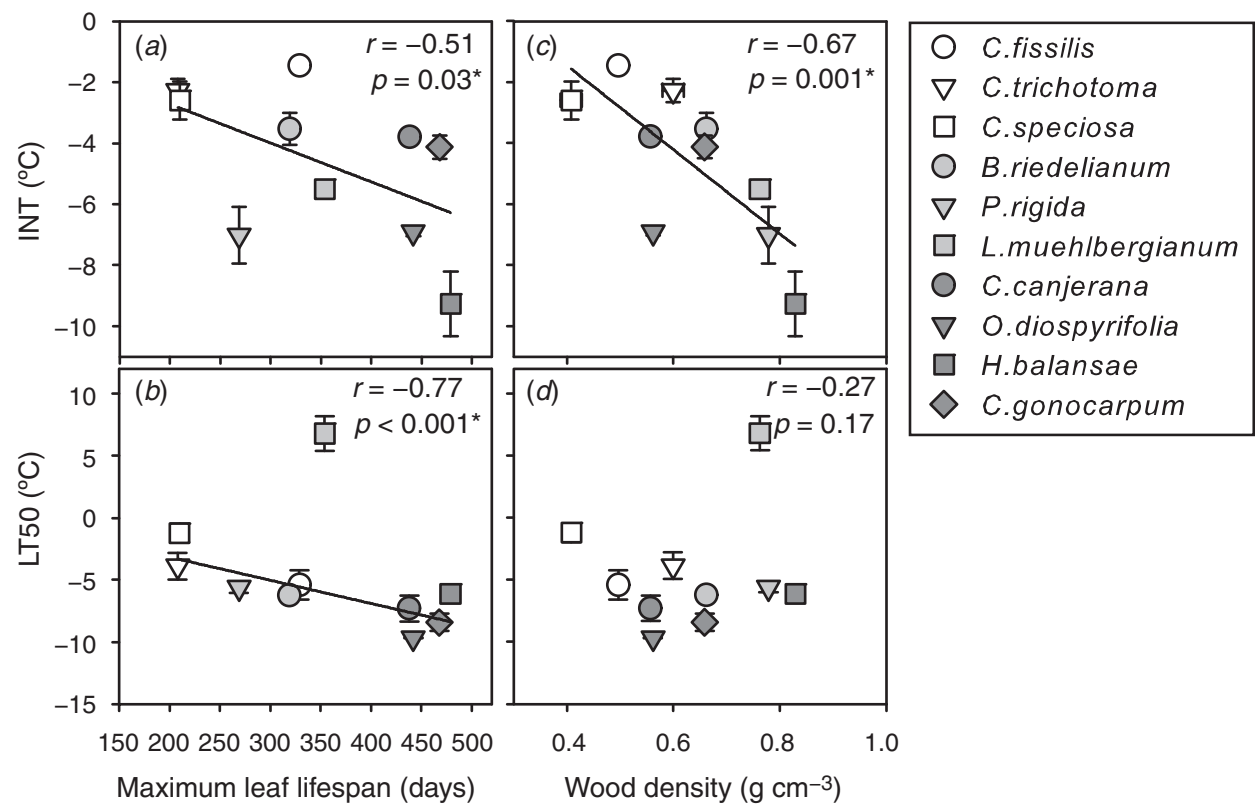

Fig. 2. Relationship between ice nucleation temperature (INT), and lethal leaf temperature (LT50) with the maximum leaf lifespan $(a, b)$, and with wood density $(c, d)$. Each point represents a species average and error bars represent \pm s.e. Lonchocarpus muehlbergianum was excluded from the correlation in $(b)$ because this species has the capacity of rolling leaves in responding to environmental stressors. The methodology used to evaluate leaf tissue damage does not allow the leaves to curl up and prevent damage from low temperatures.

Table 3. Leaf hydraulics traits

Abbreviations: TLP, turgor loss point (MPa); $\Psi_{\mathrm{md}}$, leaf water potential at midday (MPa); $\Psi_{\text {pre-dawn }}-\Psi_{\mathrm{md}}$, daily $\Delta \Psi ; K_{\text {leaf } \_ \text {max }}$, maximum leaf hydraulic conductance $\left(\mathrm{mmol} \mathrm{m}^{-2} \mathrm{~s}^{-1} \mathrm{MPa}^{-1}\right), \mathrm{P}_{50}$, hydraulic safety margin at $\mathrm{P}_{50}\left(\mathrm{HSMP}_{50}, \mathrm{MPa}\right) ; \mathrm{P}_{88}$, hydraulic safety margin at $\mathrm{P}_{88}(\mathrm{HSMP} 88, \mathrm{MPa})$

\begin{tabular}{|c|c|c|c|c|c|c|c|c|}
\hline Species & TLP & $\Psi_{\mathrm{md}}$ & $\Delta \Psi$ & $\overline{K_{\text {leaf_max }}}$ & $\mathrm{P}_{50}$ & $\mathrm{P}_{88}$ & $\mathrm{HSM}_{\mathrm{P} 50}$ & $\overline{\mathrm{HSM}_{\mathrm{P} 88}}$ \\
\hline Cedrela fissilis & $-1.18 \pm 0.02$ & $-1.45 \pm 0.09$ & $1.12 \pm 0.09$ & $35.64 \pm 3.4$ & -1.13 & -2.46 & -0.32 & 1.01 \\
\hline Cordia trichotoma & $-2.48 \pm 0.32$ & $-2.65 \pm 0.39$ & $2.22 \pm 0.32$ & $45.00 \pm 2.8$ & -0.86 & -1.55 & -1.79 & -1.1 \\
\hline Ceiba speciosa & $-1.6 \pm 0.05$ & $-1.10 \pm 0.03$ & $0.92 \pm 0.1$ & $48.46 \pm 4.6$ & -0.66 & -1.52 & -0.44 & 0.42 \\
\hline Balfourodendron riedelianum & $-2.12 \pm 0.04$ & $-2.42 \pm 0.24$ & $1.53 \pm 0.33$ & $13.4 \pm 1.2$ & -2.4 & -3.43 & -0.02 & 1.01 \\
\hline Parapiptadenia rigida & $-2.24 \pm 0.07$ & $-2.68 \pm 0.09$ & $1.4 \pm 0.05$ & $8.86 \pm 0.9$ & -1.86 & -3 & -0.82 & 0.32 \\
\hline Lonchocarpus muehlbergianus & $-1.68 \pm 0.04$ & $-0.4 \pm 0.03$ & $0.15 \pm 0.03$ & $39.14 \pm 3.2$ & -0.42 & -0.55 & 0.02 & 0.11 \\
\hline Cabralea canjerana & $-1.42 \pm 0.09$ & $-1.45 \pm 0.55$ & $1.55 \pm 0.56$ & $27.06 \pm 4.1$ & -0.49 & -1.55 & -0.96 & 0.1 \\
\hline Ocotea diospyrifolia & $-2.69 \pm 0.13$ & $-2.36 \pm 0.09$ & $2.03 \pm 0.14$ & $8.34 \pm 0.8$ & -0.52 & -0.75 & -1.84 & -1.61 \\
\hline Holocalyx balansae & $-1.87 \pm 0.11$ & $-2.54 \pm 0.08$ & $1.43 \pm 0.23$ & $18.49 \pm 1.3$ & -0.38 & -0.9 & -2.16 & -1.64 \\
\hline Chrysophyllum gonocarpum & $-2.47 \pm 0.29$ & $-2.25 \pm 0.03$ & $2.02 \pm 0.03$ & $7.51 \pm 0.8$ & -0.56 & -0.98 & -1.71 & -1.29 \\
\hline
\end{tabular}

density $(r=-0.3, P=0.08)$ (Fig. $4 a, d)$. Evergreen species, with longer LL, showed lower ETR $\max$, whereas deciduousbrevideciduous species (with lower LL) the higher $\mathrm{ETR}_{\max }$ values. The $K_{\text {leaf_max }}$ was negatively related to LL $(r=-0.6$, $P=0.002)$, and with WD $(r=-0.5, P=0.01)$. Species with longer LL and higher WD showed the lower values of $\mathrm{K}_{\text {leaf_max }}$ (Fig. 4b,e). The bulk elastic modulus $(\varepsilon)$ was positively related with LL $(r=0.5, P=0.01)$, but not with WD $(r=0.3, P=0.07$, Fig. $4 f$ ). Species with higher $\varepsilon$ (higher cell wall rigidity) had a longer LL (Fig. 4c).

\section{Leaf traits correlations network}

Trait coordination was different between deciduousbrevideciduous and evergreen species (Fig. 5; Table S1).
Evergreens showed a more complex correlation network, with more and different connections than deciduousbrevideciduous species (Table S2). In deciduousbrevideciduous species, $\mathrm{P}_{50}, \mathrm{P}_{88}$, and $K_{\text {leaf-max }}$ were the traits showing the highest values of centrality (Fig. 5a; Table S2). $\mathrm{K}_{\text {leaf_max }}, \mathrm{P}_{50}$, and $\mathrm{P}_{88}$ were positively related, indicating that species with higher water transport efficiency were more vulnerable to hydraulic dysfunction. These three traits were positively related to $\mathrm{LT}_{50}$, higher $K_{\text {leaf-max }}$ was associated with lower resistance to low-temperature damage $\left(\mathrm{LT}_{50}\right)$, whereas to lower cavitation resistance (i.e. more positive $\mathrm{P}_{50}$ and $\mathrm{P}_{88}$ ) implies lower resistance to lowtemperature damage $\left(\mathrm{LT}_{50}\right)$. In addition, $\mathrm{P}_{50}, \mathrm{P}_{88}$, and $K_{\text {leaf_max }}$ were negatively related to leaf tissue elasticity $(\varepsilon)$, 


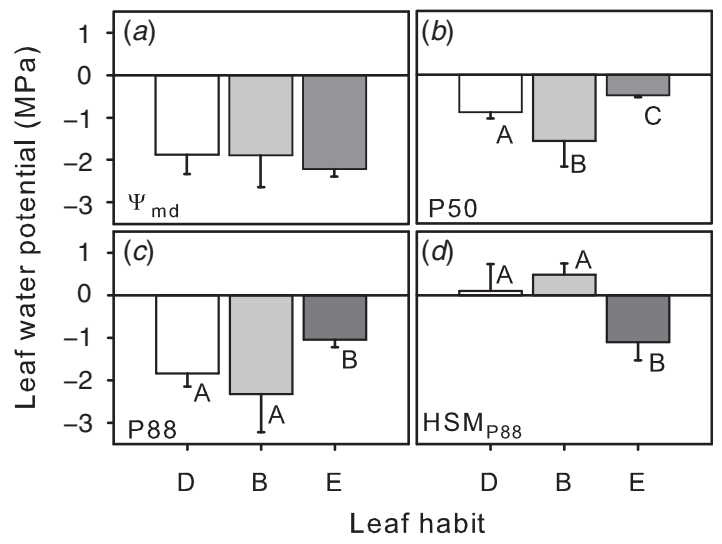

Fig. 3. (a) Leaf water potential at midday $\left(\Psi_{\mathrm{md}}\right),(b)$ water potential at $50 \%\left(\mathrm{P}_{50}\right)$, and $(c) 88 \%\left(\mathrm{P}_{88}\right)$ loss of leaf hydraulic conductance, and (d) safety margin hydraulic safety margin (HSM) $)_{\mathrm{P} 88}$ for leaf habits. D, deciduous species; B, brevideciduous species; E, evergreen species. Different letters indicate significant differences between leaf habits at $P<0.05$. so more elastic leaf tissue (lower $\varepsilon$ ) were related to lower cavitation resistance (more positive $\mathrm{P}_{50}$ and $\mathrm{P}_{88}$ ), and lower water transport efficiency (Fig. 5a).

In traits correlation network of evergreens species, $\varepsilon$ and turgor loss point (TLP) were the traits showing the highest values of centrality (Fig. $5 b$; Table S2). The $\varepsilon$ and TLP were negatively related. The $\varepsilon$ was negatively associated with $\mathrm{LT}_{50}$, $\mathrm{ETR}_{\max }, \mathrm{HSM}_{\mathrm{P} 88}$ and $K_{\text {leaf_max }}$ (i.e. plants with more rigid leaf tissue have also lower resistance to cold damage, lower maximum electron transport rate, hydraulic safety margin, and water transport efficiency), and positively to $\mathrm{P}_{88}$ (more rigid leaf tissue implies a larger vulnerability to hydraulic dysfunction). The TLP was negatively related to $\mathrm{P}_{88}$ and positively related with $\mathrm{LT}_{50}, \mathrm{ETR}_{\max }, \mathrm{HSM}_{\mathrm{P} 88}$ and $K_{\text {leaf_max }}$. Evergreens showed negative relationships between $\mathrm{P}_{50}, \mathrm{P}_{88}$ and INT, and a positive relationship with $\mathrm{LT}_{50}$, so higher vulnerability to hydraulic dysfunction imply higher temperatures of ice nucleation but also higher resistance to low-temperature damage. Also, evergreens showed a negative correlation between INT and $\mathrm{P}_{50}$ and a positive correlation

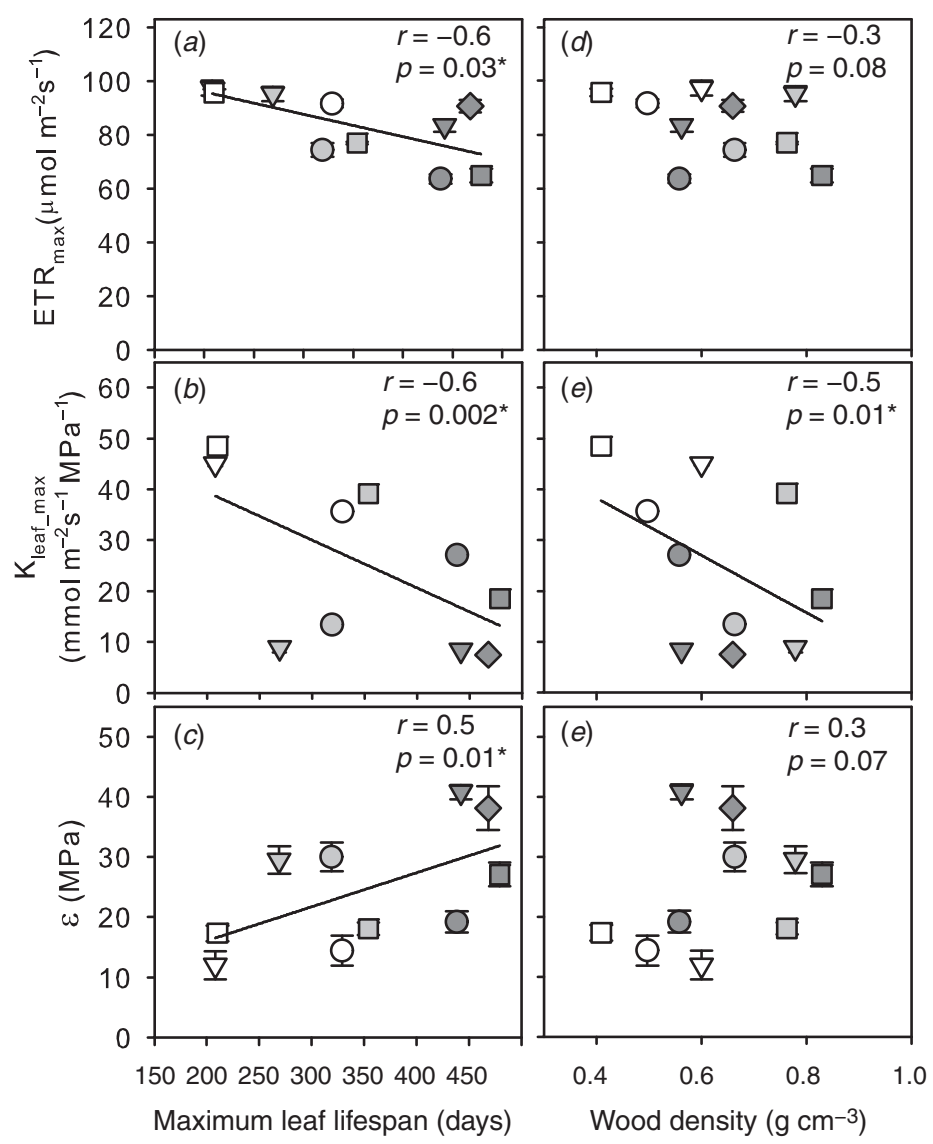

Fig. 4. Relationship between maximum electron transport rate $\left(\mathrm{ETR}_{\max }\right)$, leaf hydraulic conductance $\left(K_{\text {leaf_max }}\right)$, and volumetric bulk modulus of elasticity $(\varepsilon)$, with the maximum leaf lifespan $(a-c)$, and with wood density $(d-f)$. White symbols, deciduous species; light grey symbols, brevideciduous species; dark grey symbols, evergreen species. Different symbol shapes represent different species. See Fig. 2. 
(a)

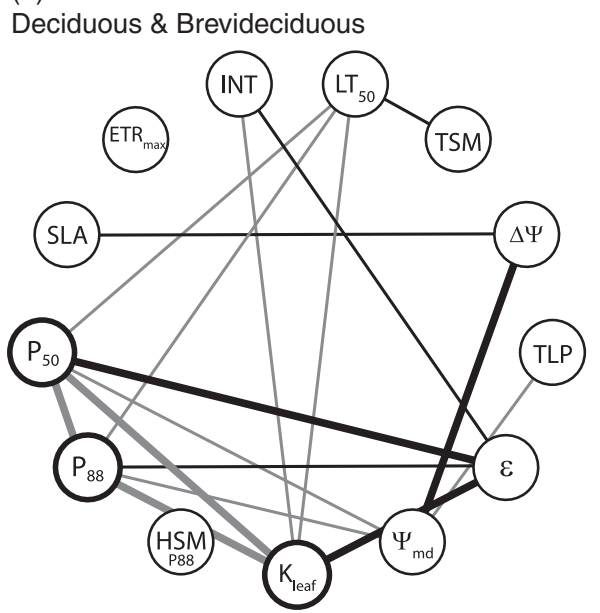

(b)

Evergreens

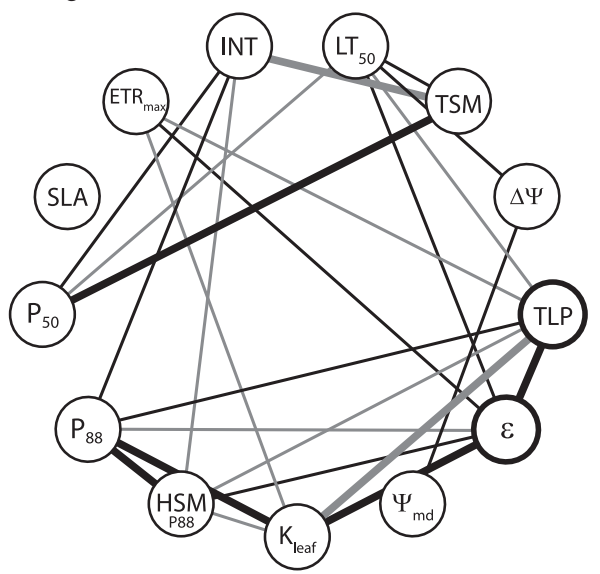

Fig. 5. Correlation networks for $(a)$ deciduous-brevideciduous and $(b)$ evergreen species leaf traits. Hydraulic traits: $\Delta \Psi$, daily difference in water potential; TLP, turgor loss point; $\varepsilon$, modulus of elasticity; $\Psi_{\mathrm{md}}$, midday water potential; $K_{\text {leaf }}$, hydraulic conductance; $\mathrm{HSM}_{\mathrm{P} 88}$, hydraulic safety margin at $\mathrm{P}_{88} ; \mathrm{P}_{88}$, water potential at $88 \%$ loss of conductivity; $\mathrm{P}_{50}$, water potential at $50 \%$ loss of conductivity. Anatomical and photosynthetic traits: SLA, specific leaf area; ETR $\max$, photosynthetic capacity measured as maximum electron transport rate. Low temperature resistance traits: INT, ice nucleation temperature; $\mathrm{LT}_{50}$, leaf lethal temperature; TSM, thermal safety margin. Grey and black lines indicate positive and negative correlations respectively. Correlation strength is represented by lines thickness. Only significant correlations with $r>0.6$ are shown. Traits identified by black circles show the highest centrality value in terms of weighted degree (the sum of all the significant coefficients of correlation of a node). For correlation coefficients, see Table S1, available as Supplementary Material to this paper. Values of INT, $\mathrm{LT}_{50}$ and TSM for Lonchocarpus muehlbergianum species were excluded from the correlation network $(a)$.

between INT and $\mathrm{HSM}_{\mathrm{P} 88}$, whereas such correlations were not found in deciduous and brevideciduous trees (Table S1). In both networks, SLA was weakly or not related to other traits.

\section{Discussion}

Our results show that evergreen and deciduousbrevideciduous species have different adaptations to cope with the consequences of subzero temperatures and water deficits. Deciduous species in our study had shorter leaf lifespan and were more efficient in leaf water transport (higher $K_{\text {leaf_max }}$ ), and showed higher photosynthetic capacity (ETR) than evergreens. These traits are linked to an acquisitive strategy, which implicate fast assimilation of $\mathrm{CO}_{2}$ during the favourable season and, consequently, exhibition of a strong seasonal pattern of growth (di Francescantonio et al. 2018). Evergreen species, on the other hand, had the opposite behaviour, with a longer leaf lifespan, lower ETR and $K_{\text {leaf_max }}$, and denser wood. These traits have been associated with a conservative strategy in the use of resources (Wright et al. 2004; Chave et al. 2009; Reich 2014), reflected in a less pronounced seasonal growth patterns throughout the year (di Francescantonio et al. 2018).

SLA was of minor importance in the present study. Contrary to relationships among SLA, and TLP, $\mathrm{P}_{50}$ or $\mathrm{K}_{\text {leaf }}$ found by other authors (e.g. Nardini et al. 2012; Simonin et al. 2012; Villagra et al. 2013), we found no significant correlations between SLA and other physiological traits. Similarly, veins density was not related to phenological patterns or stress resistance as found in other studies (Sack and Frole 2006; Nardini et al. 2012; Sack and Scoffoni 2013). This trait was very variable among species. For example, members of the Fabaceae family, such as $P$. rigida and $H$. balansae, have bipinnately compound leaves with a comparatively high density of veins that complicate the interspecific functional relationships (Fig. S6).

Contrary to our expectations, deciduous and brevideciduous species were less vulnerable to water stress events (higher $\mathrm{HSM}_{\mathrm{P} 88}$ ) than evergreen species. However, this margin was very small. Considering that air saturation deficits occurring in the region during summer can be as high as 4.0 $\mathrm{kPa}$ (di Francescantonio et al. 2018), more resistant leaves could help deciduous species to sustain high carbon assimilation and growth rates even under the least favourable conditions. We also found that deciduous and brevideciduous species show a positive relationship between leaf $\mathrm{P}_{50}, \mathrm{P}_{88}$ and $K_{\text {leaf_max }}$, (i.e. less drought-resistant species transport water more efficiently), suggesting the existence of a trade-off between the investments in construction of foliar tissues specialised in water transport and traits that provide resistance to water deficit in these groups of species. This trade-off was not observed in evergreen species. In this case, species with higher hydraulic conductance tended to have more negative $\mathrm{P}_{88}$ values (i.e. were more resistant). This could be due to the low values of hydraulic conductance of evergreens, particularly for three of the four species studied, which are consistent with other trait values typical of a conservative strategy (e.g. low photosynthetic capacity). 
Oliva Carrasco et al. (2015) showed that for the same pool of species that the safety margins calculated as the difference between minimum leaf water potential and the stem xylem pressure at the catastrophic hydraulic dysfunction level $\left(\mathrm{P}_{88}\right.$ branch) were related to sapwood capacitance in an asymptotic way. In their study, all species except the brevideciduous $P$. rigida and $L$. muehlbergianum had positive safety margins for branches. In the present study, we obtained positive safety margins for leaves of most deciduous and brevideciduous species, but for evergreens the values were negative. Evergreen species could significantly lose hydraulic conductance on a daily basis, especially during dry spells. Negative values in leaf safety margins should be relatively common (Johnson et al. 2016), and consistent with the hydraulic vulnerability segmentation hypothesis. For species with high wood density (i.e. with high construction costs) and low sapwood capacitance, such as evergreens in the present study, it would be reasonable to expect disposable leaves (negative leaf safety margins) to protect expensive stems from hydraulic failure.

Differences in the modulus of elasticity $(\varepsilon)$ could also explain differences between phenological groups. This trait represents the elasticity - or its inverse, rigidity - of the leaf tissues (Bartlett et al. 2012). Thus, $\varepsilon$ is regarded as a key leaf trait because it is functionally related to the capacity of the leaf tissue to resist drought events through cell water conservation (Salleo et al. 1997; Niinemets 2001), tolerate subzero temperatures (Scholz et al. 2012; Zhang et al. 2016), and, more recently, has been related to the rate of $\mathrm{CO}_{2}$ assimilation (Nadal et al. 2018). We found that deciduous species had more elastic leaf tissues than evergreen species, and that the elasticity of the tissues was related to the capacity of water transport in the leaves. Further, we observed that deciduous species with more elastic leaf tissues (lower $\varepsilon$ ) were those with lower resistance to hydraulic dysfunction (higher $\mathrm{P}_{88}$ and $\mathrm{P}_{50}$ ). In evergreen species, in contrast, an inverse relationship between $\varepsilon$ and $\mathrm{P}_{88}$ was found, and as observed in global datasets, a negative relationship was found between TLP and $\varepsilon$ (Bartlett et al. 2012), proving its close association with a species' level of drought tolerance. Evergreens also showed a negative correlation between cold damage $\left(\mathrm{LT}_{50}\right)$ and $\varepsilon$. This could be because more rigid cell walls increase resistance to ice formation on leaves since they confer greater mechanical resistance to the pressure exerted by ice in extracellular spaces (Yamada et al. 2002; Scholz et al. 2012; Arias et al. 2015).

Deciduous and only one brevideciduous species exhibited freezing avoidance (INT $\sim \mathrm{LT}_{50}$ ), whereas evergreen species were freezing tolerant (INT $<\mathrm{LT}_{50}$ ). Evasion mechanisms, unlike tolerance, can only be effective for a few hours (Goldstein et al. 1985; Rada et al. 1987; Sierra-Almeida et al. 2009). For Atlantic Forest species, both mechanisms are probably equally effective because low temperatures and freezing periods are relatively short in duration. We found a strong negative correlation between wood density and INT. A possible explanation is that denser woods have less water content than light woods and thus less favourable conditions to ice formation that could propagates into leaves through vascular tissues (Hacker and Neuner 2007).
In contrast, denser wood have small diameter xylem vessels that are more resistant to embolism formation due to freezingthaw cycles compared with lighter wood species (Lintunen et al. 2013). This relationship between wood density and ice nucleation temperature indirectly reflect the life history strategies of the species aimed at stress tolerance, meaning that species with higher wood density and longer LL are less frost susceptible species.

Within this group of evergreen species, a negative correlation between INT and P50 and a positive correlation between INT and $\mathrm{HSM}_{\mathrm{P} 88}$ suggest that there is trade-off in frost and drought tolerance. As previously mentioned, within evergreens, hydraulic conductance was higher in less drought susceptible species. The higher water content in leaf tissues could make them more susceptible to ice nucleation resulting indirectly in the observed trade-off between drought and frost resistance. A greater number of species need to be studied to further understand these trait associations and trade-offs within phenological groups.

The semi-deciduous Atlantic Forest constitutes the southern range limit of many species, which is reflected by the decline of tree species diversity at a regional scale from north to south (Oliveira-Filho et al. 2015). In this context, low temperatures may act as an evolutionary selective factor for some of the most frost-sensitive species limiting its distribution as occurs, for example, to the tropical palm Euterpe edulis (Gatti et al. 2008). If the occurrence of episodic spring or late frost events increases in intensity and duration as predicted for the area (Pizarro et al. 2013; Scarano and Ceotto 2015), this could have considerable ecological implications, and species with avoidance mechanisms, such as the deciduous and brevideciduous species in the present study, would be the most affected.

In summary, deciduous species presented relatively high values of safety margins, allowing them to sustain photosynthetic activity during the growing season. These species did not have hydraulic segmentation (Oliva Carrasco et al. 2015) and avoid low temperatures, both mechanisms consistent with their winter deciduousness. The absence of a dry season is likely to promote greater phenological diversity, increasing the possibility of intermediate iso- or anisohydric behaviour (Braga et al. 2016) and probably explains the weak relationship between leaf phenology and isohydricity (Fig S4). Thus, brevideciduous species exhibited hydraulic segmentation as evergreens, but also other hydraulic traits such as the safety margin that were similar to the deciduous species. Strategies for resistance to subzero temperatures were shared by both leaf habits. In contrast, species with evergreen leaves were damaged and frozen at more negative temperatures, so were more susceptible to water deficit than deciduous species. The significant loss of leaf hydraulic conductance observed in evergreens may facilitate the reduction of freezable water in tissues, and thus delay freezing under cold conditions (Arias et al. 2017). Considering all this, even though resistance to freezing and drought may share similar physiological mechanisms, adaptations must be studied within each leaf habit.

Further research is needed to elucidate resistance strategies to stress factors at whole-tree and stand levels. Resistance 
strategies, possible links between hydraulic safety and efficiencies, and carbon economy among the different phenological groups (including more species), and especially the adaptive role of wood density and elasticity within the complex of drought-frost tolerance traits require further investigation. In a climate change scenario, this will lead to a better understanding of the mechanisms of adaptation and enable prediction of interspecific variation in species' responses to future changes in environmental conditions or extreme abiotic events in the subtropical Atlantic Forest.

\section{Conflicts of interest}

The authors declare no conflicts of interest.

\section{Acknowledgements}

The authors thank Oscar Lezcano and Yamil Di Blanco for the field work. We also thank the Administración de Parques Nacionales (APN) for permitting access to the national park and the Consejo Nacional de Investigaciones Científicas y Técnicas (CONICET) and Agencia Nacional de Promoción Científica y Tecnológica (ANPCyT) through a PITEC project (Consolidación del Aglomerado Productivo Forestal Misiones y Norte de Corrientes) provided funding for this research. We are grateful to Sandra Bucci and two anonymous reviewers for their comments on the manuscript.

\section{References}

Anderegg LDL, Hillerislambers J (2016) Drought stress limits the geographic ranges of two tree species via different physiological mechanisms. Global Change Biology 22, 1029-1045. doi:10.1111/ gcb. 13148

Arias NS, Bucci SJ, Scholz FG, Goldstein G (2015) Freezing avoidance by supercooling in Olea europaea cultivars: the role of apoplastic water, solute content and cell wall rigidity. Plant, Cell \& Environment 38, 2061-2070. doi:10.1111/pce.12529

Arias NS, Scholz FG, Goldstein G, Bucci SJ (2017) The cost of avoiding freezing in stems: trade-off between xylem resistance to cavitation and supercooling capacity in woody plants. Tree Physiology 37, 1251-1262. doi:10.1093/treephys/tpx071

Atkin OK, Bruhn D, Hurry V, Tjoelker M (2005) The hot and the cold: unravelling the variable response of plant respiration to temperature. Functional Plant Biology 32, 87-105. doi:10.1071/FP03176

Bai K, He C, Wan X, Jiang D (2015) Leaf economics of evergreen and deciduous tree species along an elevational gradient in a subtropical mountain. AoB Plants 7, plv064. doi:10.1093/aobpla/plv064

Bartlett MK, Scoffoni C, Sack L (2012) The determinants of leaf turgor loss point and prediction of drought tolerance of species and biomes: a global meta-analysis. Ecology Letters 15, 393-405. doi:10.1111/ j.1461-0248.2012.01751.x

Bartlett MK, Klein T, Jansen S, Choat B, Sack L (2016) The correlations and sequence of plant stomatal, hydraulic, and wilting responses to drought. Proceedings of the National Academy of Sciences of the United States of America 113, 13098-13103. doi:10.1073/ pnas. 1604088113

Beck EH, Fettig S, Knake C, Hartig K, Bhattarai T (2007) Specific and unspecific responses of plants to cold and drought stress. Journal of Biosciences 32, 501-510. doi:10.1007/s12038-007-0049-5

Ben-Hur E, Fragman-Sapir O, Hadas R, Singer A, Kadmon R (2012) Functional trade-offs increase species diversity in experimental plant communities. Ecology Letters 15, 1276-1282. doi:10.1111/ j.1461-0248.2012.01850.x
Bhaskar R, Ackerly D (2006) Ecological relevance of minimum seasonal water potentials. Physiologia Plantarum 127, 353-359. doi:10.1111/ j.1399-3054.2006.00718.x

Björkman O, Demmig B (1987) Photon yield of O2 evolution and chlorophyll fluorescence characteristics at $77 \mathrm{~K}$ among vascular plants of diverse origins. Planta 170, 489-504. doi:10.1007/ BF00402983

Braga N da S, Vitória AP, Souza GM, Barros CF, Freitas L (2016) Weak relationships between leaf phenology and isohydric and anisohydric behavior in lowland wet tropical forest trees. Biotropica 48, 453-464. doi: $10.1111 /$ btp. 12324

Brodribb TJ, Holbrook NM (2003) Stomatal closure during leaf dehydration, correlation with other leaf physiological traits. Plant Physiology 132, 2166-2173. doi:10.1104/pp.103.023879

Buckley TN, John GP, Scoffoni C, Sack L (2015) How does leaf anatomy influence water transport outside the xylem? Plant Physiology 168, 1616-1635. doi:10.1104/pp.15.00731

Campanello PI, Mac Donagh P, Goldstein G (2009) Reduced-impact logging and post-harvest management in the Atlantic Forest of Argentina: alternative approaches to enhance regeneration and growth of canopy trees. In 'Forest management'. (Ed. SP Grossberg) pp. 39-59. (Nova Science Publishers: New York, NY, USA)

Cavender-Bares J, Cortes P, Rambal S, Joffre R, Miles B, Rocheteau A (2005) Summer and winter sensitivity of leaves and xylem to minimum freezing temperatures: a comparison of co-occurring Mediterranean oaks that differ in leaf lifespan. New Phytologist 168, 597-612. doi:10.1111/j.1469-8137.2005.01555.x

Charra-Vaskou K, Charrier G, Wortemann R, Beikircher B, Cochard H, Ameglio T, Mayr S (2012) Drought and frost resistance of trees: a comparison of four species at different sites and altitudes. Annals of Forest Science 69, 325-333. doi:10.1007/s13595-011-0160-5

Chave J, Coomes D, Jansen S, Lewis SL, Swenson NG, Zanne AE (2009) Towards a worldwide wood economics spectrum. Ecology Letters 12, 351-366. doi:10.1111/j.1461-0248.2009.01285.x

Clark JS, Bell D, Chu C, Courbaud B, Dietze M, Hersh M, Hillerislambers J, Ibáñez I, Ladeau S, McMahon S, Metcalf J, Mohan J, Moran E, Pangle L, Pearson S, Salk C, Shen Z, Valle D, Wyckoff P (2010) High-dimensional coexistence based on individual variation: a synthesis of evidence. Ecological Monographs 80, 569-608. doi:10.1890/09-1541.1

Costa e Silva F, Shvaleva A, Broetto F, Ortuo MF, Rodrigues ML, Almeida MH, Chaves MM, Pereira JS (2009) Acclimation to short-term low temperatures in two Eucalyptus globulus clones with contrasting drought resistance. Tree Physiology 29, 77-86. doi:10.1093/treephys/ tpn002

di Francescantonio D, Villagra M, Goldstein G, Campanello PI (2018) Leaf phenology and water-use patterns of canopy trees in Northern Argentinean subtropical forests. Tree Physiology 38, 1841-1854. doi:10.1093/treephys/tpy072

Di Rienzo JA, Casanoves F, Balzarini MG, Gonzalez L, Tablada M, Robledo CW (2017) InfoStat versión 2017.Available at www.infostat. com.ar [Verified 22 May 2020]

Evans RD, Black RA, Link SO (1990) Rehydration-induced changes in pressure-volume relationships of Artemisia tridentata Nutt. ssp. tridentata. Plant, Cell \& Environment 13, 455-461. doi:10.1111/ j.1365-3040.1990.tb01322.x

Galindo-Leal C, Gusmão Câmara I (2003) Atlantic forest hotspot status. In 'The Atlantic Forest of South America. Biodiversity status, threats and outlook’. (Eds C Galindo-Leal, I Gusmão Câmara) pp. 3-11. (Island Press: Washington, DC, USA)

Gatti MG, Campanello PI, Montti LF, Goldstein G (2008) Frost resistance in the tropical palm Euterpe edulis and its pattern of distribution in the Atlantic Forest of Argentina. Forest Ecology and Management 256, 633-640. doi:10.1016/j.foreco.2008.05.012 
Goldstein G, Rada F, Azocar A (1985) Cold hardiness and supercooling along an altitudinal gradient in Andean giant rosette species. Oecologia 68, 147-152. doi:10.1007/BF00379487

Hacker J, Neuner G (2007) Ice propagation in plants visualized at the tissue level by infrared differential thermal analysis (IDTA). Tree Physiology 27, 1661-1670. doi:10.1093/treephys/27.12.1661

Hasselquist NJ, Allen MF, Santiago LS (2010) Water relations of evergreen and drought-deciduous trees along a seasonally dry tropical forest chronosequence. Oecologia 164, 881-890. doi:10.1007/s00442-010-1725-y

Hódar JA, Zamora R, Peñuelas J (2004) El efecto del Cambio Global en las interacciones planta- animal. In 'Ecología.del bosque mediterráneo en un mundo cambiante'. (Ed. F Valladares) pp. 461-478. (Ministerio de Medio Ambiente: Madrid)

Holbrook NM, Zwieniecki MA (2005) 'Vascular transport in plants.' (Ed. HA Mooney) (Elsevier Academic Press: London). Available at http:// www.sciencedirect.com/science/article/pii/B9780120884575500174. [Verified 22 May 2020]

Hothorn T, Bretz F, Westfall P, Heiberger R, Schuetzenmeister A, Scheibe S, Hothorn M (2016) Package 'multcomp'. Simultaneous inference in general parametric models. (Project for Statistical Computing: Vienna, Austria)

Iida Y, Sun IF, Price CA, Chen CT, Chen ZS, Chiang JM, Huang CL, Swenson NG (2016) Linking leaf veins to growth and mortality rates: an example from a subtropical tree community. Ecology and Evolution 6, 6085-6096. doi:10.1002/ece3.2311

Jacobsen AL, Agenbag L, Esler KJ, Pratt RB, Ewers FW, Davis SD (2007) Xylem density, biomechanics and anatomical traits correlate with water stress in 17 evergreen shrub species of the Mediterraneantype climate region of South Africa. Journal of Ecology 95, 171-183. doi:10.1111/j.1365-2745.2006.01186.x

Jardim Botânico do Rio de Janeiro (2018) Flora do Brasil 2020 under construction. Available at http//floradobrasil.jbrj.gov.br. [Verified 22 May 2020]

Johnson DM, Wortemann R, McCulloh KA, Jordan-Meille L, Ward E, Warren JM, Palmroth S, Domec JC (2016) A test of the hydraulic vulnerability segmentation hypothesis in angiosperm and conifer tree species. Tree Physiology 36, 983-993. doi:10.1093/treephys/tpw031

Kitajima K, Cordero RA, Wright SJ (2013) Leaf life span spectrum of tropical woody seedlings: effects of light and ontogeny and consequences for survival. Annals of Botany 112, 685-699. doi: $10.1093 / \mathrm{aob} / \mathrm{mct} 036$

Koide RT, Robichaux RH, Morse SR, Smith CM (1989) Plant water status, hydraulic resistance and capacitance. 'Plant physiology and ecology'. (Eds RW Pearcy, J Ehleringer, HA Mooney, PW Rundel) pp. 161-183. (Chapman \& Hall: London, UK)

Körner C (2012) 'Alpine treelines. Functional ecology of the global high elevation tree limits.' (Springer Science \& Business Media: New York, NY, USA)

Leite PF, Klein RM (1990) Vegetação. In 'Geografia do Brasil: Região Sul'. (Instituto Brasileiro de Geografia e Estatística: Rio de Janeiro)

Levitt J (1980) Responses of plants to environmental stresses. In 'Chilling, freezing and high temperature stresses'. Vol. 1, 2nd edn. pp. 67-344. (Academic Press Inc.: New York, NY)

Lintunen A, Hölttä T, Kulmala M (2013) Anatomical regulation of ice nucleation and cavitation helps trees to survive freezing and drought stress. Scientific Reports 3, 2031doi:10.1038/srep02031

Lipp CC, Goldstein G, Meinzer FC, Niemczura W (1994) Freezing tolerance and avoidance in high-elevation Hawaiian plants. Plant, Cell \& Environment 17, 1035-1044. doi:10.1111/j.1365-3040.1994. tb02026.x

Martínez-Vilalta J, Mencuccini M, Vayreda J, Retana J (2010) Interspecific variation in functional traits, not climatic differences among species ranges, determines demographic rates across 44 temperate and
Mediterranean tree species. Journal of Ecology 98, 1462-1475. doi:10.1111/j.1365-2745.2010.01718.x

Maxwell K, Johnson GN (2000) Growth and chlorophyll $a$ fluorescence in Erythrina crista-galli L. Journal of Experimental Botany 51, 659-668. doi:10.1093/jexbot/51.345.659

Medeiros JS, Pockman WT (2011) Drought increases freezing tolerance of both leaves and xylem of Larrea tridentata. Plant, Cell \& Environment 34, 43-51. doi:10.1111/j.1365-3040.2010.02224.x

Nadal M, Flexas J, Gulías J (2018) Possible link between photosynthesis and leaf modulus of elasticity among vascular plants: a new player in leaf traits relationships? Ecology Letters 21, 1372-1379. doi:10.1111/ ele. 13103

Nardini A, Peda G, La Rocca N (2012) Trade-offs between leaf hydraulic capacity and drought vulnerability: morpho-anatomical bases, carbon costs and ecological consequences. New Phytologist 196, 788-798. doi:10.1111/j.1469-8137.2012.04294.x

Niinemets Ü (2001) Global-scale climatic controls of leaf dry mass per area, density, and thickness in trees and shrubs. Ecology 82, 453-469. doi:10.1890/0012-9658(2001)082[0453:GSCCOL]2.0.CO;2

Oliva Carrasco L, Bucci SJ, di Francescantonio D, Lezcano OA, Campanello PI, Scholz FG, Rodríguez S, Madanes N, Cristiano PM, Hao GY, Holbrook NM, Goldstein G (2015) Water storage dynamics in the main stem of subtropical tree species differing in wood density, growth rate and life history traits. Tree Physiology 35, 354-365. doi:10.1093/treephys/tpu087

Oliveira-Filho AT, Budke JC, Jarenkow JA, Eisenlohr PV, Neves DRM (2015) Delving into the variations in tree species composition and richness across South American subtropical Atlantic and Pampean forests. Journal of Plant Ecology 8, 242-260. doi:10.1093/jpe/rtt058

Onoda Y, Westoby M, Adler P, Choong AMF, Clissold FJ, Cornelissen JHC, Díaz S, Dominy NJ, Elgart A, Enrico L, Fine PV, Howard JJ, Jalili A, Kitajima K, Kurokawa H, McArthur C, Lucas PW, Markesteijn L, Pérez-Harguindeguy N, Poorter L, Richards L, Santiago LS, Sosinski EE, Van Bael SA, Warton DI, Wright IJ, Wright SJ, Yamashita N (2011) Global patterns of leaf mechanical properties. Ecology Letters 14, 301-312. doi:10.1111/j.14610248.2010.01582.x

Pennington RT, Lavin M, Oliveira A (2009) Woody plant diversity, evolution, and ecology in the tropics: perspectives from seasonally dry tropical forests. Annual Review of Ecology, Evolution, and Systematics 40, 437-457. doi:10.1146/annurev.ecolsys.110308.120327

Pérez-Harguindeguy N, Díaz S, Lavorel S, Poorter H, Jaureguiberry P, Bret-Harte MS, Cornwell WK, Craine JM, Gurvich DE, Urcelay C, Veneklaas EJ, Reich PB, Poorter L, Wright IJ, Ray P, Enrico L, Pausas JG, Vos AC, De , Buchmann N, Funes G, Quétier F, Hodgson JG, Thompson K, Morgan HD, Steege H, ter, Heijden MGA, Van Der, Sack L, Blonder B, Poschlod P, Vaieretti MV, Conti G, Staver AC, Aquino S, Cornelissen JHC (2013) New Handbook for standardized measurement of plant functional traits worldwide. Australian Journal of Botany 61, 167-234. doi:10.1071/BT12225

Pinheiro J, Bates D, DebRoy S, Sarkar D (2017) The Nlme package: linear and nonlinear mixed effects models. Available at https://CRAN. R-project.org/package=nlme [Accessed 10 February 2019]

Pizarro MJ, Mezher R, Mercuri P, Espíndola A, Argerich M, Fenoglio E, Castillo Marín N (2013) Tendencias de extremos climáticos en Argentina. El caso de la provincia de Misiones. Informe del Proyecto PNUD "Fortalecimiento de capacidades para contribuir a una economía de bajo carbono y resiliente al cambio climático". (INTA and SAyDS: Buenos Aires)

Poorter L, Wright SJ, Paz H, Ackerly D, Condit R, Ibarra-Manriquez G, Harms KE, Licona JC, Martinez-Ramos M, Mazer SJ, Muller-Landau C, Peña-Claros M, Webb CO, Wright IJ (2008) Are functional traits good predictors of demographic rates? Evidence from five neotropical forest. Ecology 89, 1908-1920. doi:10.1890/07-0207.1 
Prado K, Maurel C (2013) Regulation of leaf hydraulics: from molecular to whole plant levels. Frontiers in Plant Science 4, 255doi:10.3389/ fpls.2013.00255

Preston JC, Sandve SR (2013) Adaptation to seasonality and the winter freeze. Frontiers in Plant Science 4, 167doi:10.3389/fpls.2013.00167

R Development Core Team (2016). 'R: A language and environment for statistical computing.' (R Foundation for Statistical Computing: Vienna, Austria) Available at https://www.R-project.org/

Rada F, Goldstein G, Azocar A, Torres F (1987) Supercooling along an altitudinal gradient in Espeletia schultzii, a caulescent giant rosette species. Journal of Experimental Botany 38, 491-497. doi:10.1093/ $\mathrm{jxb} / 38.3 .491$

Rajashekar C, Gusta LV, Burke MJ (1979) Membrane structural transitions: probable relation to frost damage in hardy herbaceous species. In 'Low temperature and stress in crop plants'. pp. 255-274. (Academic Press: New York, NY)

Rascher U, Liebig M, Lüttge U (2000) Evaluation of instant light-response curves of chlorophyll fluorescence parameters obtained with a portable chlorophyll fluorometer on site in the field. Plant, Cell \& Environment 23, 1397-1405. doi:10.1046/j.1365-3040.2000.00650.x

Reich PB (2014) The world-wide 'fast-slow' plant economics spectrum: a traits manifesto. Journal of Ecology 102, 275-301. doi:10.1111/ $1365-2745.12211$

Rezende VL, Bueno ML, Teixeira de Oliveira-Filho A (2016) Patterns of tree composition in the southern cone of South America and its relevance to the biogeographic regionalization. Plant Ecology 217, 97-110. doi:10.1007/s11258-015-0562-9

Richardson AD, Berlyn GP (2002) Changes in foliar spectral reflectance and chlorophyll fluorescence of four temperate species following branch cutting. Tree Physiology 22, 499-506. doi:10.1093/treephys/ 22.7.499

Russo SE, Kitajima K (2016) The ecophysiology of leaf lifespan in tropical forests: adaptive and plastic responses to environmental heterogeneity. 'Tropical tree physiology'. (Eds G Goldstein, LS Santiago) pp. 357-383. (Springer International Publishing: Cham, Switzerland)

Russo SE, Cannon WL, Elowsky C, Tan S, Davies SJ (2010) Variation in leaf stomatal traits of 28 tree species in relation to gas exchange along an edaphic gradient in a Bornean rain forest. American Journal of Botany 97 , 1109-1120. doi:10.3732/ajb.0900344

Sack L, Frole K (2006) Leaf structural diversity is related to hydraulic capacity in tropical rain forest trees. Ecology 87, 483-491. doi:10.1890/ 05-0710

Sack L, Holbrook NM (2006) Leaf hydraulics. Annual Review of Plant Biology 57, 361-381. doi:10.1146/annurev.arplant.56.032604.144141

Sack L, Scoffoni C (2013) Leaf venation: structure, function, development, evolution, ecology and applications in the past, present and future. New Phytologist 198, 983-1000. doi:10.1111/nph.12253

Sakai A, Larcher W (1987) 'Frost survival of plants responses and adaptation to freezing stress.' (Springer-Verlag: Berlin, Germany)

Salleo S, Nardini A, Gullo MAL (1997) Is sclerophylly of Mediterranean evergreens an adaptation to drought? New Phytologist 135, 603-612. doi:10.1046/j.1469-8137.1997.00696.x

Santiago LS, Goldstein G, Meinzer FC, Fisher JB, Machado K, Woodruff D, Jones $T$ (2004) Leaf photosynthetic traits scale with hydraulic conductivity and wood density in Panamanian forest canopy trees. Oecologia 140, 543-550. doi:10.1007/s00442-004-1624-1

Scarano FR, Ceotto P (2015) Brazilian Atlantic forest: impact, vulnerability, and adaptation to climate change. Biodiversity and Conservation 24, 2319-2331. doi:10.1007/s10531-015-0972-y

Scholz FG, Bucci SJ, Arias NS, Meinzer FC, Goldstein G(2012) Osmotic and elastic adjustments in cold desert shrubs differing in rooting depth: coping with drought and subzero temperatures. Oecologia 170, 885-897. doi:10.1007/s00442-012-2368-y
Schwabe WW, Lionakis SM (1996) Leaf attitude in olive in relation to drought resistance. Journal of Horticultural Science 71, 157-166. doi:10.1080/14620316.1996.11515392

Scoffoni C, Albuquerque C, Brodersen CR, Townes SV, John GP, Bartlett MK, Buckley TN, McElrone AJ, Sack L (2017) Outside-xylem vulnerability, not xylem embolism, controls leaf hydraulic decline during dehydration. Plant Physiology 173, 1197-1210. doi:10.1104/ pp. 16.01643

Sierra-Almeida A, Cavieres LA, Bravo LA (2009) Freezing resistance varies within the growing season and with elevation in high-Andean species of central Chile. New Phytologist 182, 461-469. doi:10.1111/ j.1469-8137.2008.02756.x

Simonin KA, Limm EB, Dawson TE (2012) Hydraulic conductance of leaves correlates with leaf lifespan: implications for lifetime carbon gain. New Phytologist 193, 939-947. doi:10.1111/ j.1469-8137.2011.04014.x

Squeo FA, Rada F, Azocar A, Goldstein G (1991) Freezing tolerance and avoidance in high tropical Andean plants: is it equally represented in species with different plant height? Oecologia 86,378-382. doi:10.1007/ BF00317604

Srur M, Gatti F, Benesovsky V, Herrera J, Melzew R, Camposano M (2007) 'Identificación, caracterización y mapeo de los ambientes del Parque Nacional Iguazú.' (Puerto Iguazú, Argentina)

Stemke JA, Santiago LS (2011) Consequences of light absorptance in calculating electron transport rate of desert and succulent plants. Photosynthetica 49, 195-200. doi:10.1007/s11099-011-0026-y

Stuart SA, Choat B, Martin KC, Holbrook NM, Ball MC (2007) The role of freezing in setting the latitudinal limits of mangrove forests. New Phytologist 173, 576-583. doi:10.1111/j.1469-8137.2006.01938.x

Tyree MT, Hammel HT (1972) The measurement of the turgor pressure and the water relations of plants by the pressure-bomb technique. Journal of Experimental Botany 23, 267-282. doi:10.1093/jxb/23.1.267

Uriarte M, Swenson NG, Chazdon RL, Comita LS, John Kress W, Erickson D, Forero-Montaña J, Zimmerman JK, Thompson J (2010) Trait similarity, shared ancestry and the structure of neighbourhood interactions in a subtropical wet forest: Implications for community assembly. Ecology Letters 13, 1503-1514. doi:10.1111/ j.1461-0248.2010.01541.x

Villagra M, Campanello PI, Bucci SJ, Goldstein G (2013) Functional relationships between leaf hydraulics and leaf economic traits in response to nutrient addition in subtropical tree species. Tree Physiology 33, 1308-1318. doi:10.1093/treephys/tpt098

Vitasse Y, Lenz A, Körner C (2014) The interaction between freezing tolerance and phenology in temperate deciduous trees. Frontiers in Plant Science 5, 541doi:10.3389/fpls.2014.00541

Wilner J (1960) Relative and absolute electrolytic conductance test for frost hardiness of apple varieties. Canadian Journal of Plant Science 40, 630-637. doi:10.4141/cjps60-093

Wisniewski M, Neuner G, Gusta LV (2015) The use of high-resolution infrared thermography (HRIT) for the study of ice nucleation and ice propagation in plants. Journal of Visualized Experiments 99, e52703. doi: $10.3791 / 52703$

Wolfe BT, Kursar TA (2015) Diverse patterns of stored water use among saplings in seasonally dry tropical forests. Oecologia 179, 925-936. doi: $10.1007 / \mathrm{s} 00442-015-3329-z$

Wright IJ, Reich PB, Westoby M, Ackerly D, Baruch Z, Bongers F, Cavender-Bares J, Chapin T, Cornelissen JHC, Diemer M, Flexas J, Garnier E, Groom PK, Gulias J, Hikosaka K, Lamont BB, Lee T, Lee W, Lusk C, Midgley JJ, Navas M-L, Niinemets U, Oleksyn J, Osada N, Poorter H, Poot P, Prior L, Pyankov VI, Roumet C, Thomas SC, Tjoelker MG, Veneklaas EJ, Villar R (2004) The worldwide leaf economics spectrum. Nature 428, 821-827. doi:10.1038/ nature 02403 
Wright SJ, Kitajima K, Kraft N, Reich P, Wright IJ, Bunker DE, Condit R, Dalling JW, Davies JD, Diaz S, Engelbrecht B, Harms KE, Hubbell SP, Marks CO, Ruiz-Jaen MC, Ssalvador CM, Zanne AE (2010) Functional traits and the growth-mortality trade-off in tropical trees. Ecology 91, 3664-3674. doi:10.1890/09-2335.1

XuF, Guo W, Xu W, Wei Y, Wang R(2009) Leaf morphology correlates with water and light availability: what consequences for simple and compound leaves. Progress in Natural Science 19, 1789-1798. doi:10.1016/j. pnsc.2009.10.001

Xu X, Medvigy D, Wright SJ, Kitajima K, Wu J, Martins GA, Salenska S, Pacala S (2017) Variations of leaf longevity in tropical moist forests predicted by a trait-driven carbon optimality model. Ecology Letters 20, 1097-1106. doi:10.1111/ele.12804
Yamada T, Kuroda K, Jitsuyama Y, Takezawa D, Arakawa K, Fujikawa S (2002) Roles of the plasma membrane and the cell wall in the responses of plant cells to freezing. Planta 215, 770-778. doi:10.1007/s00425-002-0814-5

Zhang YJ, Bucci SJ, Arias NS, Scholz FG, Hao GY, Cao KF, Goldstein G (2016) Freezing resistance in Patagonian woody shrubs: the role of cell wall elasticity and stem vessel size. Tree Physiology 36, 1007-1018. doi:10.1093/treephys/tpw036

Zuloaga F, Morrone O, Belgrano M (2008) 'Catálogo de plantas vasculares del Cono Sur.' (Missouri Botanical Garden Press: St Louis, MO, USA)

Handling Editor: Wieland Fricke 